Wilfrid Laurier University

Scholars Commons @ Laurier

3-4-2016

\title{
Objecting (to) Infrastructure: Ecopolitics at the Ukrainian Ends of the Danube
}

Tanya Richardson

Wilfrid Laurier University, trichardson@wlu.ca

Follow this and additional works at: https://scholars.wlu.ca/anth_faculty

Part of the Anthropology Commons, International Relations Commons, and the Nature and Society Relations Commons

\section{Recommended Citation}

Tanya Richardson (2016) Objecting (to) Infrastructure: Ecopolitics at the Ukrainian Ends of the Danube, Science as Culture, 25:1, 69-95, DOI: 10.1080/09505431.2015.1081503

This Article is brought to you for free and open access by the Anthropology at Scholars Commons @ Laurier. It has been accepted for inclusion in Anthropology Faculty Publications by an authorized administrator of Scholars Commons@ Laurier. For more information, please contact scholarscommons@wlu.ca. 
For a special issue on Infrastructuring Environments in Science as Culture 25(1) 2016.

Tanya Richardson is an anthropologist and Associate Professor in the Department of Global Studies at Wilfrid Laurier University. Her research addresses the politics of nature conservation and ecological restoration around Ukraine's Danube Delta.

\title{
Tanya Richardson
}

Wilfrid Laurier University

Department of Global Studies

75 University Ave.

Waterloo, ON

N2L 3C5 Canada,

trichardson@wlu.ca

\section{Objecting (to) Infrastructure: Ecopolitics at the Ukrainian Ends of the Danube.}

\author{
Tanya Richardson \\ Wilfrid Laurier University
}

\begin{abstract}
In southern Ukraine, two hydraulic infrastructures continue to exist despite environmentalist campaigns that have exposed them as fragile, broken or unprofitable. The Danube-Dnister Irrigation Project (DDIS), a Soviet mega-project that diverted water from the Danube and turned the Sasyk estuary into a reservoir, receives state funding despite a 1994 ban on its use for irrigation. The Bystre Shipping Canal, built in 2004 despite domestic and international opposition, is losing money but continues to operate. These cases exemplify the material politics of infrastructuring in which infrastructure is understood as an antagonistic process of assembling networks of humans and nonhumans rather than a fixed facility. This approach helps explain how the confluence of unruly coastal matters and the politics of expertise have facilitated these shipping and irrigation infrastructures' re-embedding in bureaucratic networks. These cases show that obduracy and fragility, as well as visibility and invisibility - conditions that figure prominently in infrastructure studies — should be considered in terms of oscillation rather than as ontologically distinct or static conditions. This analysis also highlights the limits of the modernist search for scientific certainty in resolving environmental conflicts in Ukraine, and some possibilities to experiment politically with new decision-making procedures. This account can thus serve as a "story that intervenes" by pointing beyond reform impulses that re-enact modernist narratives of progress within a strict nature-society divide.
\end{abstract}

Key words: material politics, obduracy, irrigation, shipping, Danube, Black Sea

\section{Introduction}

"Give the lyman back to the children!" These words were painted on the poster of a schoolgirl standing with a group of protesters on a $14 \mathrm{~km}$ long dike dividing Lake Sasyk from the Black Sea in Tatarbunary District, Ukraine. On August 24, 2008 - Ukraine's independence day - roughly 500 farmers, pensioners, teachers, schoolchildren, businesspeople, and officials from settlements near Sasyk joined environmentalists to protest the government's failure to open the dike and "return Sasyk to the sea."

Thirty years earlier the concrete, stone, and sand dike had been built in order to cut the Sasyk lyman (estuary) off from the Black Sea and turn it into a $210 \mathrm{~km}^{2}$ freshwater irrigation reservoir for the Danube-Dnister Irrigation Project (DDIS). After pumping Sasyk's salt water into the Black Sea, engineers filled its basin with Danube water via a $13.5 \mathrm{~km}$ long feeder canal dredged through the Danube floodplain. Danube water was then moved through a system of canals, pumps, and pipes to Sasyk's east side where it was used to irrigate 29,000 hectares of land.

Figure 1. Map of Lake Sasyk and surrounding districts highlighting key components of the DDIS. Map by Iryna Iakovlieva. 
This attempt to turn a lagoon into an irrigation reservoir was a disaster. Village wells turned saline; elevated levels of sodium ions and chloride salts damaged soil; toxic algae blooms flourished; therapeutic muds became saturated with heavy metals; and residents experienced increased prevalence of rashes, respiratory diseases and certain cancers. Despite nearly two decades of activism and expert studies recommending restoration the authorities have failed to address Sasyk's ecological problems.

Figure 2. Demonstrators digging up Sasyk's dike. August 24, 2008. Photo by Maxim Iakovliev.

After a priest said a prayer, protesters began to dig a channel from the dike to the sea before an audience of nervous police and journalists from prominent regional and national media outlets. An environmental lawyer was on site to advise demonstration organizers - environmentalists from a local NGO, the director of the Danube Biosphere Reserve, and 30 village residents. Elderly people shed tears at the sight of the water flowing into their newly dug channel and the once familiar smell of sea-saturated mud.

Later the organizers issued a statement to regional authorities declaring residents' willingness to use their own heavy equipment to break the dike if the regional authorities did not take action. After a week spent fielding journalists' questions, the governor finally agreed to fund a new working group. While this led to a 2009 regional government resolution to rehabilitate Sasyk, the working group was shut down after Viktor Yanukovich was elected president in 2010 . The system remains intact and employs at least 120 people, including many as security guards at pumping stations without electricity and stripped of equipment.

Figure 3. Map of the Danube Biosphere Reserve and the Kilia Delta. Prepared by Iryna Iakovlieva. Background map courtesy of the U.S. Geological Survey.

Several years earlier in 2002-04, some of the demonstration's organizers had campaigned to halt the Ukrainian government's plans to dredge a shipping canal in the Bystre Branch of Ukraine's Danube Delta, roughly 40 kilometers south of Sasyk. The government aimed to restore national prestige and increase prosperity in Ukraine's depressed Danube region by breaking Romania's monopoly on delta shipping. Sensitive ecological habitats in the Kilia Delta (where Bystre is located) had been recognized as globally significant in conservation circles and comprised part of the core zone of Ukraine's Danube Biosphere Reserve, part of a UNESCO Transboundary Biosphere Reserve. Despite fierce domestic and international opposition, the government rezoned the reserve, allowing the state enterprise Delta-Lotsman to build the canal.

However, during the canal's first year of operation, sand and silt deposited during flooding and winter storms restored Bystre's mouth to its original depth. Not until a 2.5 kilometer-long stone breakwater was finally completed several years later could Delta-Lotsman reliably maintain the canal's projected depth. While the canal operates and is no longer the object of heated dispute, it is considered unprofitable, and has failed to provide local employment

Figure 4. Dredging ship and breakwater in Bystre Canal on August 14, 2013. Photo by Maxim Iakovliev.

This paper presents the controversies around these shipping and irrigation projects in order to examine the practices and politics of infrastructuring coastal environments where the Danube River meets the Black Sea. This paper poses two key questions. Why do these infrastructures - one broken and one operating at a loss - still exist? And how can an STS-informed analysis of these infrastructures serve as a "story that intervenes" in the cases at hand - and perhaps more ambitiously in debates about reform in post-revolutionary Ukraine? To develop a comparative analysis of these cases, I draw on anthropology and STS literatures on knowledge controversies and infrastructures, along with scholarship on the environmental politics and history of rivers. The empirical material includes interviews, news reports, technical reports, and observations from brief site visits to the canal and parts of the irrigation infrastructure gathered during annual ethnographic research trips between 2008 and 2013.

These cases differ in important ways. The DDIS involved a much more radical transformation of the coastal environment. It is a "project of the century" of Soviet vintage (Josephson, 1995) while the Bystre Project 
was initiated by Ukraine's government during the second decade of the contemporary Ukrainian state's existence. The shipping infrastructure provoked an international dispute even before construction began while the other conflict has remained largely a local and regional issue. Yet both infrastructures display similarities in their ability endure powerful objections by environmental activists and countervailing forces of Danube and Black Sea matters.

This paper unfolds as follows. First, I discuss how analyzing the case as a material politics of infrastructuring can help explain the similar dynamics of fragility, controversy and obduracy that characterize these shipping and irrigation infrastructures. Second, I demonstrate how configurations of knowledge practices, bureaucratic politics, and unanticipated responses of Danubian and Black Sea matters disrupted the capacity of these infrastructure projects to function as planned. The third and fourth sections compare the ways in which these infrastructures' exposure as fragile generated ecopolitics which in turn forced responses from the infrastructures' proponents. However, the confluence of unruly coastal matters and the politics of expertise have enabled these infrastructures to bureaucratically re-embed themselves and to persist in spite of activist campaigns.

\section{Material politics of infrastructuring}

Brian Larkin has evocatively described infrastructures as "matter that enables the movement of other matter" $(2013,329)$. The Danube, like other rivers, simultaneously exists as the matter that infrastructure circulates, and as the infrastructure that enables other matter to move. Its waters hydrate cities, irrigate crops, and generate power while its channels have long served as a transportation route for goods and people (Schmid, 2013). However, infrastructures are built networks and thus rivers' existence as infrastructure involves their incorporation into them (Larkin, 213, 330; Carse 2012). Rivers' dual capacity to serve as infrastructure and provide matter for other infrastructural projects vividly illustrates Star and Ruhleder's key point that infrastructure is a relational concept (1996). Infrastructure is therefore best examined not as "hardware" or "fixed facilities" but rather as a process - as infrastructuring - by paying careful attention to how infrastructure comes into existence in relation to organized "technical, material and knowledge interventions" and through "infrastructural work" (Blok et al., Schick \& Winthereik, and Nakazora, all 2016 in this issue; Carse, 2012; Edwards, 2003; Star and Ruhleder, 1996, p.113). Consequently, infrastructure is always a social and political matter as much as it is a technical one.

The functioning, breakdown, and controversies of infrastructure can be better explained by analyzing infrastructures' ecology, i.e. the assemblages of humans and nonhumans that make up a given infrastructure and into which it is or should be embedded (Star and Ruhleder, 1996). Distant relations, sites, and elements may be essential to the existence of an infrastructure and must be unraveled or interrupted if it is to be redesigned, challenged or dismantled. Conceptualizing infrastructures as the webs of relations of which they are composed is also instructive when considering the politics of infrastructuring environments around the Danube Delta.

Environmental historians have detailed the ways in which infrastructure is the meeting point for knowledge, technical systems, biologies and earth systems (Carse, 2012; Pritchard, 2011). However, scholarship on the environmental politics and history of rivers also demonstrates the capacity of water and sediments to complicate the merging of the natural and technical in the building and maintenance of dams, dikes, and irrigation systems. For example, in spite of dams and hydroelectric plants, the Columbia River retains its "unmade" qualities and cycles that challenge human efforts to control them (White, 1995). This is also evident on the Nile (where the Aswan Dam's construction led to the proliferation of mosquitoes and to a devastating epidemic), and in the Mekong Delta (where tides, river currents, and sediments undermined French colonial hydraulic infrastructure projects, and US military campaigns) (Biggs, 2010; Mitchell, 2002).

What is striking about the DDIS and the Bystre Canal is how infrastructures have been exposed as fragile and incapable of delivering what was intended, and yet manage to endure in the face of "objections" from humans and nonhumans. Infrastructure conjures solidity, a solidity that is sometimes deliberately made visible to display state power (Larkin, 2013). Yet "infrastructure is a dense interwoven fabric that is, at the same time, dynamic, thoroughly ecological, even fragile" (Bucciarelli in Star, 1999, 377). According to Star, this fragility is often most visible at moments of breakdown. However, infrastructure exposed as fragile or vulnerable may also be obdurate; and infrastructures' visibility may be constant or intermittent but not necessarily spectacular. ${ }^{1}$

Obduracy is complex and can be brought into being by a wide range of factors beyond technical functioning (Hommels, 2005). It is conditioned by the different ways infrastructure is embedded in space and

\footnotetext{
${ }^{1}$ I thank a reviewer for highlighting the point about visibility.
} 
other networks (Star, 1999). This may include capital investments literally sunk in specific locations, e.g. water networks, railroads, and pipelines. It may include the worldviews of groups of professionals have been trained to see a problem in a particular way (Hommels, 2005, 29). For example, Soviet understandings of social needs in Russian industrial cities and the heating infrastructures that had emerged as a result of them constrained the implementation of neoliberal reforms in post-Soviet Russia of the 1990s (Collier, 2011). Thus, to analyze these cases the fragility/obduracy and visibility/invisibility dichotomies that frame many infrastructure studies need to be conceived in a nonoppositional, oscillating manner like the natural resources that they circulate (Richardson and Weszkalnys, 2014, 15).

Although Larkin (2013) claims that infrastructure becomes infrastructure when "the tension between local and global is resolved" the cases of the DDIS and the Bystre Canal show that infrastructure can exist in spite of the fact that connections are constantly interrupted or problematized by humans and nonhumans (2013). In the Bystre case, environmental activists, Romanian officials, and river and sea sediments stymied Ukrainian government efforts to insert the Bystre Branch into the $7^{\text {th }}$ European Transportation Corridor. International actors (e.g. Romanian and European Commission officials) and domestic actors (environmentalists, Reserve personnel, scientists) appealed to Ukrainian and international law to interrupt the connecting of the local and the global thereby making the Bystre branch-as-infrastructure a disputed matter. Siltation at Bystre's mouth halted the operation of the canal for long periods between 2004 and 2009 and on several occasions since.

Environmental activism around the DDIS focused on breaking connections established by the irrigation system (between the Danube and Sasyk) and reestablishing those that the DDIS severed (between Sasyk and the Black Sea). While the presence of ions, salts and toxins in the water ultimately led to a ban on irrigation, the flourishing of fish (albeit disease-ridden) proved a powerful ally for DDIS managers and an obstacle to the environmentalists. These infrastructures are thus better conceptualized as being comprised of divergent, partially connected worlds where friction or "weediness" is more commonplace than free-flowing circulation (Jensen and Winthereik, 2013).

This paper examines the role of ecopolitics in infrastructural oscillations between fragility and obduracy. Ecopolitics refers not only to the activists, scientists or administrators who speak (and act) on behalf of nonhuman beings and habitats, but also the nonhumans that induce these interventions. The DDIS and the Bystre Project became "matters of concern," that is controversies outside of which scientists and experts are unable to stand and generate consensus with their knowledge (Latour, 2004). Ecopolitics in the Danube are conceptualized here in terms of "material politics," an approach to the study of politics that simultaneously addresses knowledge controversies and the ways in which materials' unruliness can become the locus of dispute and disagreement (Barry, 2001; 2013; Latour, 2005).

Materials of irrigation and shipping infrastructure - water, ions of sodium and chloride, sediments, toxins, canals and a dike - became integral to and generative of conflicts due to their ability to resist political control (Barry, 2001, 2013). Barry argues that we should not see these materials as wholly independent actors because like humans, they are entangled with information and regulation that makes them into particular kinds of objects (2013). The capacities of the Danube's suspended sediments and the Black Sea water's ions are sometimes activated by specific entanglements with information and regulation. However, at other times they have a force like floods and earthquakes that exceeds knowledge, "forces thought," and can change politics (Stengers, 2010; Whatmore, 2013).

The two infrastructure projects are similar in the way their creators' high modernist "simplification" of natural environments subsequently threatened to undermine the projects (Scott, 1998; Mitchell, 2002). However, the political economy of science and the conditions for expressing disagreement differed dramatically between the Soviet Union of the 1970s and post-Soviet Ukraine in the early 2000s. In the USSR, research was entirely state funded and was conducted in the Academy of Sciences and in various industry-affiliated research institutes (Graham and Dezhina, 2008).

In the 1960s, the Ministry of Water Resources came to dominate the development process and in southern Ukraine focused on the intensification and chemicalization of agriculture (Bressler, 1995, 247; Vlasenko and Polishchuk, 2008). Thus there was little scope for scientists outside this ministry - let alone concerned villagers - to criticize its inter-basin water transfer projects such as the Danube-Dnipro complex of which the DDIS was one component (Bressler, 1995; Josephson, 1995). Consequently, the project became controversial in the Soviet Union only after it failed to deliver irrigable water and to increase crop yields (Rusev, 1996). Although the DDIS's failure helped to stimulate a regional environmental movement in the late 1980s, financial crisis and democratization of the Ukrainian state after the Soviet Union's disintegration enabled Sasyk to become a full-fledged public controversy (Richardson, 2016). 
By contrast, the Bystre project was initiated a decade after Ukraine's independence. The 1990s saw a massive expansion of environmental governance initiatives which Ukraine's new government joined. Scientific budgets were slashed, researchers' salaries were meager, and research itself - particularly in the former industryrelated institutes (e.g. related to water and fisheries management) - came to operate to a large extent on a market basis (Ninetto, 2005). However, the canal project was undertaken during President Leonid Kuchma's second term when the country's Transport Ministry dominated the formation of government policy and even trumped the Foreign Ministry (Fedorenko, 2006). Nevertheless, Kuchma's Ukraine has been characterized as "competitive authoritarianism" whose control over civil society was incomplete (Way, 2005). Indeed, the government underestimated Ukrainian environmental NGOs' organizing abilities, legal knowledge and international connections.

My goal goes beyond explaining these infrastructures' persistence in terms of their oscillations between conditions of obduracy/fragility and visibility/invisibility. Telling a story of heterogenous nature-cultures and environmentalists' efforts to give nonhumans' interests political representation might provoke both "critics" and "defenders" of the projects to rethink their modernist faith in the capacity of scientific facts to settle these disputes (Campbell, 1985, Latour, 2004). These stories might also remind advocates of radical modernization programs in post-Maidan Ukraine, that leaving out political representation for nonhumans risks repeating the environmental destruction that modernist visions (socialist and capitalist) enable.

\section{Fragility}

Engineers overlooked much scientific research when they brought together technical, biological and hydrological systems to built the DDIS and the Bystre Canal (Carse, 2012). In order to make visible the matters that would subsequently disrupt these projects' realization, let me introduce the places that were transformed. The Danube, Europe's second largest river, is its most turbid. The roughly 35 million tons of sediment it carries to its mouth are a key factor in the formation of its delta (Mikhailov, 2004, 59). The delta is said to begin at the Izmail promontory where the Danube splits into the Tulchea and Kilia Branches, the latter of which forms the international border between Romania and Ukraine and, since 2007, an external border of the EU (since Ukraine is not a member).

While political boundaries have changed multiple times over the past two hundred years, roughly $80 \%$ of the delta is located in Romania and 20\% in Ukraine. The Tulchea Branch (Romania) breaks into the Sulina and Sf. Gheorghe Branch (both shipping canals), while the Kilia Branch splits into the Ochakiv and Starostambul Branches just below the town of Vilkove which in turn divides into smaller branches, one of which is Bystre. Whereas the delta as a whole is roughly 4700 years old, the Kilia delta began forming roughly 350 years ago (Kovalenko et al., 2009: 66-67). While the speed at which it is extending seaward slowed after the construction of Serbia's Iron Gates dams in the 1970s and 80s, delta-formation processes are active and dynamic.

The 100-meter wide, 13.5-kilometer long Danube-Sasyk canal along which water flows to Sasyk begins several kilometers upstream from Vilkove. Sasyk was a lyman (or liman in Russian). Lymans are estuaries, lagoons or bays on the Northwest Black Sea coast that form at river mouths where the flow is blocked by a bar of sediments (Vlasenko and Polishchuk, 2008, 4). Sasyk was the southernmost and largest of a series of lymans located between the Dnister and the Danube rivers. Lymans (usually in submerged river valleys) pulsate over time and have a dynamic hydrological regime such that over decades their depth and salinity varies. Some lymans' sand spits have openings allowing water to circulate (as with pre-DDIS Sasyk) while others do not (Ibid). Hyper-saline water layered in lens-like formations rises through springs and enter the lyman from underground. There are also thick layers of salt-saturated mud on Sasyk's bottom. Indeed, Sasyk's muds were known to have healing properties while its sanatoriums were well known in Romania and the Soviet Union.

Similar to other megaprojects (e.g. Mitchell, 2002) a number of miscalculations led to the DDIS' inability to produce water with the appropriate chemical composition for irrigating the southern chernozem (black earth) soils of the surrounding Budzhak steppe. While activists think the project would have failed in any case, some engineers and scientists argue the system may have worked if different technical decisions had been made. According to an engineer still employed in the DDIS, the Danube-Sasyk Canal channeled water into the southern part of the lyman (near the Black Sea) rather than in its northern part as a cost-cutting measure. The Danube water was thus unable to circulate properly even though an additional pumping station was built on Sasyk's northeast side to improve it. This engineer also explained that in the rush to finish the system, the basin of Sasyk was washed out twice instead of three times.

The saltwater springs were another problem. According to a biochemist at the Institute of the Biology of the Southern Seas, if these springs had been plugged, it may have been possible to maintain levels of ions of 
sodium, potassium and calcium and chloride and sulfate salts that would not damage soils. Despite inappropriate $\mathrm{pH}$ levels and levels of certain ions and salts, thousands of hectares were irrigated (Vasenko et al, 2004). The soil's structure was so transformed that it could not be ploughed. Technicians were given permission to add acid to reduce the $\mathrm{pH}$ and gypsum to bond with sodium.

Although soil damage and lowered agricultural productivity did generate criticism of the project in the 1980s, Sasyk became a full-blown "matter of concern" only after the Soviet Union's demise. In 1984 a report to the Central Committee of the Communist Party sharply criticized Ukraine's Ministry of Water Resource for allowing irrigation with saline water (Rusev, 1996, 10). A report from the Academy of Sciences Institute of Productive Forces recommended stopping irrigation and opening the dike. Critical reports succeeded in halting the construction of the second phase of the project but irrigation continued.

The Soviet Union's disintegration made the ecological conditions worse because the DDIS could no longer afford to run the system's energy-intensive main pump. Toxic algae blooms intensified. Residents complained openly to their parliamentary deputy and to the ecological inspection agency about the foul smells of toxic algae, and about rashes, respiratory diseases, and cancers. The deputy helped create an NGO and thus began a new phase of opposition to the DDIS and a campaign to "return Sasyk to the sea." Born 1971 in Tatarbunary, Iryna Vykhrystiuk took on the leadership in 1996 and has been central in keeping the campaign going. An engineer by training, she became Vidrodzhennia's director after her superior in the State Ecological Inspection stymied her efforts to get answers about Sasyk's water quality. Although the NGO activists have been unable to secure a Cabinet of Ministers decision to open the dike, they have achieved oblast and district-level resolutions calling for rehabilitation and have forced water department officials to respond.

While the DDIS project to "freshen" Sasyk had no local precedent, the history of shipping in the Danube Delta might have been instructive for the Bystre Canal's creators. In the mid $19^{\text {th }}$ century English engineer Charles Hartley identified the hydrological challenges of building canals through the delta in his report to the Danube Commission. He noted that engineers would constantly battle against bar formation which would require dredging and constant extending of jetties into the sea (Shtefan, 2003). In the early $20^{\text {th }}$ century, a Russian-built canal in the Ochakiv branch quickly filled with sediments (Ibid). After World War II the Prorva Canal was dredged in the Kilia Delta's Ochakiv Branch and maintained until 1994. Between the 1950s and the 1980s, the amount of sediment dredged increased twentyfold; the canal required round-the-clock dredging because it was gradually becoming extinct (Fedorenko, 2006, 17). While the Soviet Union could afford this, Ukraine's cashstrapped government could not. Moreover, transportation volumes had fallen due to the wars in the former Yugoslavia in parte because debris from bombed bridges blocked the river.

Scholarly and activist discussions of the conflict over shipping in Ukraine's Danube Delta often focus on the violation of environmental laws. However, in debates about canal projects, coastal geomorphology, bar formation at Bystre's mouth, and their probable impact on the technical and economic feasibility of the project were key matters of dispute. Transport Ministry officials argued that Bystre's natural depth meant it would require minimal dredging. Project engineers made calculations that downplayed the force, volume and dynamics of the sediments and currents of river and sea (Fedorenko, 2006).

When Vasyl Fedorenko, Deputy Director of the Danube Biosphere Reserve (henceforth DBR) asked the project's chief engineer why the costs of continual dredging had not been incorporated the engineer replied: "What are you saying? When we dredge the bar to a depth of seven meters, the currents from the sea will be so strong we'll have to reinforce the banks at Bystre's entrance, not continuously dredge it!" This implied that bar formation at Bystre's mouth worked according to completely different laws of physics than Sulina's mouth (which after 150 years had jetties that were $8 \mathrm{~km}$ long). Put poetically in the words of an engineer who proposed an alternative project, "A sandbar is a living being. It moves, it changes. This has to be taken into account" (Zizak, 2003). It wasn't.

The Black Sea current that affects Bystre's mouth most moves from the northeast. Thus to protect the canal a long jetty should be constructed perpendicular to the current. However, a jetty of only $410 \mathrm{~m}-$ not connected to the mainland - was built in time for the canal's opening on August 24, 2008. It came as no surprise to DBR administrators and other critics that during the canal's first winter the depth of water over the sandbar at the mouth was restored from seven meters to its original depth of $3.5 \mathrm{~km}$ due to flooding and storms - "unmade" natural cycles (White, 1995). A year after the project began, four times more sediments had been dredged than originally projected. While the project planned for the passage of 1340 ships in year one, only 775 actually passed through (Fedorenko, 2006). As of 2006, the project's cost was double the Academy of Sciences' more expensive alternative project (ibid, 35), a familiar story in the history of large-scale hydraulic infrastructure projects (Mitchell, 2002). Delta-Lotsman could not maintain the project depth with any reliability until the fall of 2009 when a $2.5 \mathrm{~km}$ long breakwater was completed. 
Even so, the force of winter storms and the annual deposition of silt during floods create obstacles to the canal's maintenance. When I visited it with hydrobiologists from the Academy of Sciences on August 1, 2013, the reserve warden at the Bystre post had not seen ships pass for weeks. Although the Danube did not overflow its banks in the Ukrainian delta that summer, as it did further upstream, it did leave a particularly large silt deposition, which, combined with a sudden drop in water, had created additional work for the single dredging ship. Meanwhile, according to DBR Director Alexander Voloshkevich, parts of the breakwater have subsided due to the weight of the granite stones and the softness of the earth, which allows seawater and sand to penetrate. He also noted that its atypical scythe-like shape (built in anticipation of a port) had in fact exacerbated the collection of sediments and accelerated the formation of reedbeds adjacent to it. As I stood on the breakwater looking westward towards Bystre I could see a light green haze against the stones of the jetty where reeds were starting to grow.

\section{Controversy}

The properties of Danube water circulating through irrigation and shipping infrastructures provoked environmental campaigns - one largely local and the other international in scope. Both exerted significant pressure on government departments and state enterprises and forced them to respond. Both cases were knowledge controversies in that they involved producing and disputing the claims of expert studies and in both cases unruly materials and determined activists forced the government to generate more information on the infrastructure projects' influence on Black Sea coastal environments (Latour, 2004, Barry, 2013). However, instead of providing rationales for their dismantling, the information enabled officials responded in ways creating the oscillation between fragility and obduracy.

According to Iryna Vykhrystiuk, once Vidrodzhennia's activists and village heads had consolidated the public on whose behalf they would speak by conducting village surveys, they "turned to science." Neither the parliamentary deputy nor residents had been able to access official reports or information on the DDIS that might serve as a starting point to build on the "knowledge-making moments" of residents" "quotidian acts of breathing, drinking, and smelling" (Murphy, 2013, 1). Iryna obtained a $\$ 500$ grant from a US foundation to commission an independent expert study of fish pathologies and Sasyk's toxicological condition. Distrustful of scientists working in many research institutes that had participated in the DDIS's construction, Iryna turned to an ichthyologist and a biochemist in the nearby Moldovan Academy of Sciences, one of whom had grown up near Sasyk and witnessed its transformation. Levels of heavy metals (zinc, cadmium, lead, nickel, copper, chromium) in mud were found to be higher than the accepted norm and were elevated in fish. This modest expert study thus translated polluting elements in the land, water, mud and fish invisible to the human eye into figures that could travel and be compared with state standards (Callon, 1986).

The report was sent to the Kyiv Institute of Independent Experts, whose director had played a key role in halting the expansion of the DDIS. He sent a team of experts, including a soil specialist, a hydrobiologist, and an agronomist. One of the scientists who had participated in designing the DDIS said incredulously "This cannot be" while observing Sasyk's eroding banks and stagnating water. These scientists' study formed the basis of a petition to the Cabinet of Ministers. The subsequent meeting only called for more research - a pattern that would be repeated over the subsequent decade.

Using this evidence, the NGO made Sasyk visible to a national public in 1999-2000 through attracting media attention about the ecological disaster the DDIS had created. Iryna and her colleagues worked with a supportive head of the district state administration and secured a district council resolution calling for Sasyk's restoration. This in turn was used to pressure regional (oblast) and national authorities. However, the supportive head of the local state administration was removed soon after making critical comments about the DDIS at a roundtable where Irrigation and Water Department officials were present. Undeterred, the NGO got another grant to hire an engineering firm to design a project to open the dike. This 2002 report too was ignored.

After Iryna wrote letters to the President and Prime Minister, the Ministry of Environment was ordered to commission a report from its Kharkiv-based Institute for Ecological Problems. This 200-page, state-funded, official expert study published in 2004 provided extensive data on the hydrological, ecological and toxicological situation in support of residents and activists' claims (Vasenko et al 2004). However, oblast and district authorities continued to defer a decision and to sideline activists.

Fed up, activists organized the demonstration described above. Iryna admitted that residents would not use their excavators without a formal de-diking decision because it was illegal and their equipment would be impounded. It was meant to be a "show" to attract publicity in order to pressure the government. It worked because during Viktor Yushchenko's government officials did strive to be publically accountable. 
However, the preparation of a technical-economic report to outline the rehabilitation design stalled. Water Department officials and their allies insisted that the rehabilitation project resolve a series of other problems simultaneously in addition to opening the dike: provide drinking water for a village that is now dependent on the Danube-Sasyk Canal and for villages around Sasyk; and supply irrigable water (from the canal) to Sasyk's east side. The regional government did not have sufficient funds to pay for this kind of project design. Iryna insisted that the money could have been found from other state programs if officials had made the effort. The DDIS' infrastructured water - particularly the Danube-Sasyk canal - thus proved to be particularly obdurate because of its potential to meet domestic and agricultural needs in a drought-prone region, and because of the bureaucratic complexities of obtaining funding for a project that would satisfy all interested parties at once.

After Viktor Yanukovich's election as President in January 2010, the process was transferred back to the Cabinet of Ministers. Although an inter-departmental group met once in the fall of 2010, the process has been stalled ever since. The governor and other local, regional and national officials were replaced with loyal members of the president's Party of Regions. They consolidated into a highly centralized regime in which patron-client relationships predominated that did away with distinctions between business and the state to a greater degree than ever before and enabled the webs of relations of which the DDIS is comprised to re-embed themselves in wider networks (Minakov, 2014, Star, 1999).

Whereas the DDIS became controversial after its launch and a full-fledged "matter of concern" more than decade after it first caused problems, the Bystre canal project generated controversy even before it was built. During the 1990s, a massive expansion of multilateral environmental agreements took place in the context of Ukraine's foreign policy goal of European integration, many of which applied to the Danube Delta. Nature protection in Ukraine's Kilia Mouth actually began in the Soviet period with the creation of a reserve in 1967 and its subsequent enlargement in 1981 to form the 14,000 ha Dunaiskii Plavni zapovednik (Richardson, 2015). In 1995, the Kilia Mouth was listed as Ramsar site and World Bank projects funded the creation of Biosphere Reserves in Romania and Ukraine and the creation of a joint UNESCO Transboundary Biosphere Reserve. Ukraine also signed other conventions such as the Danube River Protection Convention (1994), the Bern Convention (1979), the Espoo Convention (1991), the Aarhus Convention (1998), and a bilateral Treaty with Romania on Border Matters (Koyano, 2009). The reserves' establishment not only strengthened the position of birds, plants and sediment formations as a bulwark against large-scale infrastructure projects, but also embedded their "spokespeople" (Latour, 2004) - reserve personnel and activists - in transnational networks of scientists and environmental organizations.

The "Danube Delta Conflict" - as it is known in international law circles - was a series of disputes in response to the government's selection of the Bystre option for its canal (Koyano 2009). It can be considered what Barry (2012) calls a "political situation," a term expressing how conflicts proliferate and so change identities over time. A dispute emerged initially between the DBR and the Academy of Sciences on the one hand and the Ministry of Transport (and the government) on the other. However, the government's 2003 choice of Bystre then provoked an international dispute with Romania on grounds that it did not provide an adequate Environmental Impact Assessment report or conduct proper public consultation. The Romanian government later filed complaints under the Espoo and Aarhus Conventions claiming that dredging in the Ukrainian delta would cause sediment flows that might damage its delta and its canal. Ukraine's government also received warnings and compliance requests under other conventions (e.g. Ramsar, Bern).

The bitter dispute between the DBR, the Academy of Sciences and the Ministry of Transport emerged after Delta-Lotsman failed to provide requested information on the project for the Academy of Sciences to comparatively evaluate all canal projects. DBR Director Alexander Voloshkevich showed me the letter he received from the Ministry of Transport dated July 12, 2001 in response to the request for information. It stated that it was impossible to provide the requested information and the Ministry "draw[s] the conclusion that the essence of your letter is to openly sabotage the process of preparing a report in the given period." The Academy of Sciences' critical evaluation of the Bystre project and recommendation of an alternative project was ignored.

Concerned about harm to bird, fish, and plant habitats and the DBR's integrity, Ukrainian environmental NGOs mobilized against the project on a variety of fronts. Although activists regularly picketed government buildings in Kyiv, much of their work involved letter writing, organizing petitions, and launching court cases against the government. The Lviv-based NGO "Environment-Law-People" initiated lawsuits against the government for its failure to comply with Ukrainian legislation on environmental impact assessment and wrote letters of complaint to the Aarhus Convention compliance committee and the European Commission. Ukraine's WWF office was also actively involved in writing letters to the Ukrainian government and to the European Union. NGOs in Kyiv, Kharkiv, and Odessa pressured officials to provide information and to conduct environment impact assessments properly. The NGO Vidrodzhennia organized public event at the boat terminal 
in Vilkove - the town near the DBR - to speak with residents and to share information about the DDIS's failure. While the majority of townspeople supported the canal's construction because they believed government promises of job creation, the activists found sympathetic listeners among young people (see Udovichenko, 2003).

Transport Ministry officials mobilized presidential powers and the state's coercive apparatus against the DBR to achieve their goal of building the canal. The Ministry faced several lawsuits, one of which sought to invalidate its land title to the Reserve. In February 2004 a Presidential Decree changed the Bystre Channel zoning from "core zone" to "anthropogenic zone." This removed a key obstacle to implementing the project; the challenge to the reserve's title was still winding its way through the court system. The DBR was also audited by various inspection agencies, tactics used frequently at the time to "close mouths" and make insubordinate state employees follow orders. This culminated in the launch of a criminal investigation of reserve personnel for abuse of office in the fall of 2004 (Voloshkevych, 2004). The spurious charges and the seizure of the Reserve's computers led many DBR employees to campaign for the opposition candidate Viktor Yushchenko in the November 2004 presidential elections. In January 2005, after the dramatic events of the Orange Revolution, Yushchenko was elected president on a platform of democratic reform and EU integration.

Sediments and currents continued to be an important force in the politics around the canal. The exposure of the canal's siltation (and impassibility) and the embezzlement of state funds after the Orange Revolution, led to the firing of Delta-Lotsman's director and the halting of funding in August 2005. The new government began to provide some of the information requested by the various parties and to begin a dialogue with EU and Romanian officials on the canal. However, the canal project resumed again in 2006; the canal was reopened on a trial basis in 2007 and officially again after the breakwater was constructed in 2009 .

The resumption of work resulted in Romania's filing a complaint under the Espoo Convention and the issuing of a caution to Ukraine. Thus, even though Yushchenko's government performed some of what was expected under international environmental regulation the operation of the canal resumed. Some say it was initiated again because so much had already been invested and to delay further would mean the loss of the canal because of continued siltation (Koyano, 2009). Although the DBR administrators stopped their active opposition to the project, they did scrutinize dredging practices. Their observations of silt plumes led them to believe that sediments were not being dumped $20 \mathrm{~km}$ at sea as they should be, and their complaints helped modify dredging practices in order to minimize damage to delta ecologies.

\section{Obduracy}

Despite all their fragilities, the DDIS and the Bystre Canal still exist. Why? Here I detail some factors contributing to these systems' obduracy. I address two issues regarding the DDIS: the role of fish and a fishery in extending and embedding the networks interested in the DDIS's continued existence (cf. Hommels 2005) and the demand for and impossibility of establishing certainty about the impact of de-diking (cf. Campbell 1985). In the case of Bystre, these networks are less visible, so I can only speculate. The occlusion (or ignorance) of complex ecologies seriously undermined the functioning of the shipping and the irrigation projects. Nevertheless these infrastructures' materialities, and the ways in which they became embedded in bureaucratic networks, enabled them to change in ways that created intransigent obstacles for those trying to dismantle them.

In 2003, the Odessa State Water Department (of which the DDIS is part), the governor of Odessa Oblast and the State Fishing Committee worked together to change the status of Sasyk from a water reservoir (vodokhospodarske) to a fishery reservoir (rybokhospodarske). This consolidated an assemblage resistant to opening the dike and dismantling the DDIS. Irrigation from the reservoir was banned in 1994 due to water quality but continued on a few hundred hectares until 2000. When irrigation ceased, and when Vidrodzhennia's 2002 report demonstrated the costs of maintaining the system, the rationale for maintaining the reservoir in its freshwater state in service of irrigation also weakened.

The reservoir had been stocked with a type of Asian carp to minimize algae growth and soon became populated with Danube fish. Fishing brigades formed to catch fish even though a commercial fishery was never included in the original plan for the system. However, in the early 2000s fish populations were in decline. Faced with the criticism and declining fish stocks, the changed status of the water would ensure artificial stocking took place so that commercial fishing could be enhanced and formalized.

Agencies responsible for confirming that a water body meets environmental standards (sanitaryepidemiological and veterinarian services) turned a blind eye to the toxicological situation and approval for the establishment of a fishery. The change in status enabled a firm to rent the water body from the State Fishing Committee (Vykhrystiuk, 2010). In this way, Sasyk's fish populations - albeit contaminated - enabled the Water Department officials to embed the DDIS in networks external to it and to multiply the actors interested in its 
continued existence (see Starr, 1999, Hommels, 2005). During a conversation in June 2011, Iryna admitted that changing the reservoir's status created one of the most difficult obstacles in arguing for dismantling the DDIS.

Another challenge activists face is disagreement among experts about how Sasyk's hydrology will change, what kinds of interventions are needed to prevent the ecological situation from worsening, and how to deal with people who have become dependent on the Danube-Sasyk Canal. The problem of restoring the ecosystem is an example of a knowledge controversy whose resolution is complicated by the fact that no one body of experts has a monopoly on expertise, that is, they cannot claim to know the whole situation (Barry, 2013). Moreover, bureaucrats responsible for the decision assume that all claims of scientific experts should align in making certainty claims about the existence of a degraded environment around Sasyk and the benefits that will accrue from de-diking. Yet, as sociologists of science have demonstrated, "the existence of certainty is the result of continual interpretation and negotiation" (Campbell, 1985, 430). In the context of the McKenzie pipeline hearings in Canada, Campbell describes the specific ways scientists' invocation of certainty and uncertainty claims were related to their position as "critics" or "defenders" (439).

In the Sasyk case, the different uses of certainty became sharply visible in expert statements provided to the inter-departmental commission which was created in 2010 after the closure of the regional government's working group. There was wide variety in the use of (un)certainty claims by experts in the fields of ichthyology, hydrology, hydrobiology, hydrochemistry, economics, and tourism made arguments. According to Iryna (who attended the meeting) those institutions involved in designing and managing the DDIS provided data and expert assessment that recommended against rehabilitation. Those that had argued for rehabilitation provided evidence in support of opening the dike. Scientists were thus unable to establish consensus on what would happen upon de-diking (see Latour 2004). The absence of certainty - and the assumption that it could and must be achieved enabled officials to delay a decision, and to repeatedly commission expert studies.

One contentious issue concerns the way Sasyk's hydrology will change after de-diking. According to a hydrochemist from the Institute of Marine Biology, algae blooms will continue if the opening in Sasyk's dike is not kept clear and if circulation is not ensured. Prior to diking, Sasyk's sand spit had openings that would shift their location over time in relation to Black Sea currents. It is too costly and unfeasible to remove the entire dike, and so one or two openings of 150-200 meters must be made and kept clear of sand. Further, according to a former Water Department administrator some state body needs to take responsibility for managing this system. Given chronic shortage of budget financing, neither the district, nor the Danube Basin administration, nor the Water Department would want to take responsibility for this non-profit-generating operation. (Activists claim that if a government decision to rehabilitate Sasyk were actually made, private donors and citizen groups could be mobilized to take care of most of the remaining issues). A final example concerns contradictory reports by hydrologists about whether Sasyk will flood or drain out completely when the dike is broken. Some claim the Black Sea level is falling and thus that Sasyk's water will all drain out; others claim that the sea is rising and that Sasyk will flood if the dike is opened.

If one consequence of organizing to de-dike Sasyk has been the production of an excess of contradictory expert studies by specialists of different profiles, the problem Bystre's critics face is inadequate information particularly concerning its economic profitability. In August 2013, Oleg Rubel from the Institute of Market Problems and Environmental Research and DBR director Alexander Voloshkevych both thought the Bystre canal would soon close - possibly even in the upcoming year - because of its unprofitability. However, their arguments were based on indirect information and observations. Even leading economists from the Institute of Market Problems have difficulty acquiring information to assess the canal's income-generating capacity. According to Oleg Rubel, Delta-Lotsman has existed since 1998 and since 2003 has had a monopoly on collecting fees for the use of all Ukraine's canals. The reporting structure for the firm - headquartered in the city of Mykolaiv - publishes data on the number of ships but not on the size of the cargo. It is by calculating the volume of cargo that one can assess the canal's income.

Moreover, as the economic crisis in the country has deepened, the ability of the company to cover losses in the Bystre canal has been reduced; fewer ships using Bystre means tariffs on other canals have to be raised in order to subsidize the canal. Delta-Lotsman's access to collecting these fees across the country was also being undermined as the ownership of port and canal infrastructure underwent another restructuring in 2013. Rubel and Voloshkevych thus speculated that the economic interest in keeping the canal running could disappear.

The economics of shipping in the delta do not work in favour of the canal either (Pigareva, 2012). The economic crisis in Europe dramatically reduced the volume of cargo. A month-long freeze in the winter of 2012 caused serious losses to shipping firms and to firms administering canals. Not only were there difficulties in maintaining a depth for ships with a draft of $5.85 \mathrm{~m}$ to pass. Ultimately Bystre could not compete with Romania's Sulina canal even by offering lower prices because the Sulina canal enabled ships with a draft of 7 
meters to pass. Beyond this, more ships were using the shorter route of Romania's Cernovoda Canal which cuts out passage through the delta entirely. Moreover, the Romanian government had found a legal provision under which it could insist that any ships using Romanian rivers or seaports were obliged to use exclusively Romanian canals (Alexander Voloshkevich, personal communication). Thus many ships that did use the Bystre canal on their way back out to the Black Sea after unloading their cargo could no longer do so. This further reduced the tariffs Delta-Lotsman collected.

However, in December 2013 the canal avoided death. Prime Minster Nikolai Azarov announced a new, billion dollar largely state-funded programme for the development of the Danube Region. Some of these funds were for deepening the Bystre Canal so that ships with a seven-meter draft could pass. Money was also allocated to develop port infrastructure and to help the struggling shipping industry in the region. In one report, a deputy indicated that one reason for the programme was to buttress the region against Romanian irredentism.

This government has since been toppled as a result of Ukraine's Maidan Revolution. The state coffers are empty; the government has received IMF funding and passed new anti-corruption laws. It is in the process of (slowly) cleaning out various corrupt schemes. In December 2013 it seemed as if the canal would get another lease on life. In a situation where the Ukrainian government is waging an undeclared war against Russia, where Odessa Oblast became part of the zone claimed as "New Russia," and where Mikheil Saakashvili, ex-President of Georgia, has been appointed as Head of Odessa Oblast, the canal's future remains uncertain.

\section{Conclusion: from oscillation to experimentation?}

This paper has examined two cases where hydraulic infrastructure exposed as fragile or broken nevertheless remains stubbornly obdurate. One case involves the Danube-Dnister Irrigation Project (DDIS), a failed Soviet-era irrigation mega-project that still receives state funding despite a persistent environmental campaign and a ban on irrigating from Lake Sasyk. The second concerns the Bystre canal which was built despite domestic and international opposition and continues to operate - likely at a loss - despite having failed to generate development in Ukraine's Danube region.

Analyzing these cases as a "material politics" of infrastructuring helps explain their similar dynamics of fragility, controversy and obduracy (Barry 2013). As this research suggests, conditions that figure prominently in infrastructure studies - obduracy and fragility, as well as visibility and invisibility - should be considered in terms of oscillation rather than as ontologically distinct or static conditions (see Hommels, 2005; Star and Ruhleder, 1996). This move helps bring infrastructuring into focus as an ongoing process rather than a series of discrete states of being and dovetails with other arguments that "friction" is more commonplace in infrastructures' existence than free flowing circulation (Jensen and Winthereik 2012).

It is tempting to explain these situations in terms of economic and political interests, as do many of the people I've spoken with. This explanation overlooks the active part played by nonhuman aspects - e.g. sea currents, sediments, sand, ions, toxins, canals and the dike - in the oscillations of irrigation and shipping infrastructure between the Danube and the Black Sea. These things have been forceful presences in this story, undermining the efforts of those trying to build infrastructure and those trying to dismantle it.

These systems' fragility was exposed when water, salt, sediments and sea currents did not behave as anticipated. These infrastructures' anticipated or actual fragility and the consequences of their malfunctioning played a prominent part in motivating environmental activists to organize campaigns against them. In both cases, expert knowledge about the nonhuman entities thought to cause the systems' failure or its harm to other beings became a key part of the struggle (Barry, 2013). However, information did not necessarily enable campaigners to prevent the canal's construction or initiate the DDIS's dismantling. This was due to more than the cunning of the infrastructures' proponents. First, the behaviour of deltaic and coastal matters and the infrastructure's materiality (e.g. the dike) also posed challenges to activists. Second, the divergence of scientists' claims, in a context where consensus is required, enabled managers to maintain the status quo.

In the case of the Bystre canal, obtaining adequate information to compare alternative projects was difficult, generating a vicious struggle between different state structures. While eventually the Ukrainian government produced more detailed environmental assessment reports - in a sense, submitting to the discipline of new environmental regulation - this did not stop construction of the canal. It was inserted into transportation networks but has had to cease operations periodically and is reputed to be unprofitable. But sediments and currents continued to exert a force in politics (Whatmore, 2013; Stengers, 2010). They undermined project initiators, who lost their jobs after the government changed. Although the canal project was suspended, the risk that siltation would make all the other investment unusable led officials to resume construction and maintenance work. 
Meanwhile, when the NGO Vidrodzhennia challenged the irrigation system, an unintended consequence was an information excess with divergent claims. Scientists could not produce a consensus about what Sasyk's condition is and what will happen after de-diking. Such disagreement was used to delay a decision (cf. Latour, 2004; Barry, 2013). Vidrodzhennia's persistent production of information exposed the DDIS' futility and high cost, with the hope that rational bureaucrats would see the light and disembed the irrigation system.

However, activists were confronted with the capacity of irrigation and water department officials to consolidate links with the bureaucratic networks of the Fishing Committee. Such linkages were partly thanks to fish populations, which (even if diseased) could sustain a fishery. In such ways, water and irrigation officials ensured a rationale for funding the DDIS, even though it could not irrigate. DDIS could withstand activist challenges, partly through experts' worldviews and invisible networks in rendering infrastructure obdurate, as observed more generally by Hommels and Starr.

How might this account itself serve as a "story that intervenes"? Under President Yanukovich, my answer would be: none, likely. Over the first three years of his rule, opportunities for public debate and contentious citizen engagement shrank dramatically. Had the Maidan Revolution not occurred, these opportunities would likely have become even more limited during Yanukovich's attempt to retain power in the 2015 presidential elections.

In post-revolutionary Ukraine, possibilities for political experimentation still exist, though they are limited by oligarchy's resilience, and by Russia's hybrid war against the country that has made security and sovereignty the number one priorities. Yet, it might be possible to create an assembly space where interests of humans and nonhumans can be represented without the modern expectation that scientists can establish "matters of fact" which end the dispute. For example, in the restoration of Munich's section of the Iser, "science, politics, and nature forfeited their unquestioned authority", and "politicians, administrators, scientists, the public, civil society, as well as the river and its inhabitants sit with their representatives at the negotiating table" (Kropp, 2005, p.490). Given the right administrative support, could Sasyk be a place to experiment politically with new decision-making procedures?

This story might also intervene in response to reform impulses (among scholars, policy makers and activists) that re-enact modernist narratives of progress with a strict nature-society divide. On the one hand, some claim that only a radical modernization program to create a liberal capitalist state can save Ukraine from the clutches of neo-Soviet paternalism and engulfment by Russia. On the other hand, an influential Kyiv-based environmentalist has initiated legislative changes to implement his vision of "absolute nature protection" (absolutna zapovidnist), a version of fortress conservation that would ban all human interaction with and management interventions into protected areas. A familiar binary story: on the one side politics, on the other nature. Yet, at this political opening where the preparation of a new national constitution is on the horizon, perhaps political experimentation could occur here too, in ways that set nature-society relations on a new footing. For inspiration Ukraine could look beyond Europe to the Ecuadorian constitution, which gives nature rights and gives humans rights to use nature to sustain themselves.

In closing, it is worth remembering that Ukraine is home to the Chernobyl plant, whose meltdown provoked many influential works on rethinking nature-society relations and the limits of scientific certainty (Beck, 1992; Petryna, 2002). May the lessons of Chernobyl, and other environmental disasters such as Sasyk, be remembered in the rush to modernize. And may the war not suffocate possibilities for political experimentation or take the lives of those with the energy, courage, and creativity to undertake it.

\section{Acknowledgements}

This research has been supported by a standard grant from the Social Sciences and Humanities Research Council of Canada (grant no. 210156). I am grateful to Sergei Diatlov, Vasyl Fedorenko, Oleg Rubel, Igor Studennikov, Alexander Voloshkevych, and Iryna Vykhrystiuk for facilitating this research and for helping me better understand the details of these cases. Iryna Iakovleva, Anastasiia Miliukova, Julia Serbina, and Louise Robert provided excellent research assistance. I thank the participants of the Ukraine Research Group for their comments on an earlier draft of this paper, particularly the discussant, Maria Sonevytsky. Anders Blok, Derek Hall, Kristina Lyons, Gisa Weszkalnys, and two reviewers shared thoughtful comments that have greatly improved this paper's arguments and presentation.

\section{Sources}

Barry, A. (2001) Political Machines: Governing a Technological Society, (London: Althone Press). 
Barry, A. (2012) Political Situations: Knowledge Controversies in Transnational Governance. Critical Policy Studies. 6, pp. 324-336.

Barry, A. (2013) Material Politics: Disputes Along The Pipeline, (Malden: Wiley-Blackwell).

Beck, Ulrich. (1992) Risk Society: Towards a New Modernity, (London: Sage Publications).

Biggs, D. (2010) Quagmire: Nature and Nation Building in the Mekong Delta, (Seattle and London: University of Washington Press).

Blok, A., B. R. Winthereik and M. Nakazora (2016) Introduction: Infrastructuring Environments, Science as Culture 25(1)

Bressler, M. (1995) Water Wars: Siberian Rivers, Central Asian Deserts, and the Structural Sources of a Policy Debate, Rediscovering Russia in Asia: Siberia and the Russian Far East, pp. 240-255 (M.E. Sharpe).

Campbell, B. L. (1985) Uncertainty as Symbolic Action in Disputes Among Experts. Social Studies of Science 15, pp. 429-53.

Callon, M. (1986) Some Elements of a Sociology of Translation: Domestication of the Scallops of St. Brieuc Bay, Power Action and Belief: A New Sociology of Knowledge, pp. 196-223 (London: Routledge).

Carse, A. (2012) Nature as Infrastructure: Making and Managing the Panama Canal Watershed. Social Studies of Science, 42, pp. 539-563.

Collier, S. J. (2011) Post-Soviet Social: Neoliberalism, Social Modernity, Biopolitics, (Princeton: Princeton University Press).

Edwards, P. N. (2003) Infrastructure and Modernity: Force, Time, and Social Organization in the History of Sociotechnical Systems. In T. Misa, P. Brey \& A. Feenberg (Eds.) Modernity and Technology. Cambridge, MA: The MIT Press, pp. 184-225.

Fedorenko, V. (2006) Conservation in the Danube Delta and Shipping [in Russian] (Vilkovo: Art Vision).

Graham, L and D. Dezhina. (2008) Science in the New Russia: Crisis, Aid, Reform. (Bloomington: Indiana University Press).

Hommels, A. (2005) Unbuilding Cities: Obduracy in Urban Sociotechnical Change, (Boston: MIT Press).

Jensen, C.B. and B.R. Winthereik. (2013) Monitoring Movements of Development Aid: Recursive Partnerships and Infrastructures, (Cambridge: MIT Press).

Josephson, P. R. (1995) "Projects of the Century" in Soviet History: Large-Scale Technologies from Lenin to Gorbachev, Technology and Culture 36(3), pp. 519-559.

Koyano, M. (2009) Effective Implementation of International Environmental Agreements: Learning Lessons from the Danube Delta Conflict, Public Interest Rules of International Law: Towards Effective Implementation (Burlington VT: Ashgate), pp.

Kropp, C. (2005) River Landscaping in Second Modernity, Making Things Public: Atmospheres of Democracy Making Things Public: Atmospheres of Democracy pp. 486-491 (Boston: MIT Press).

Larkin, B. (2013) The Politics and Poetics of Infrastructure, Annual Review of Anthropology 42, pp. 327-343.

Latour, B. (2004) The Politics of Nature: How to Bring the Sciences into Democracy, (Cambridge: Harvard University Press). 
Latour, B. (2005) From Realpolitik to Dingpolitik, or, How to Make Things Public, Making Things Public: Atmospheres of Democracy pp. 14-41 (Boston: MIT Press).

Mikhailov, V.N. ed. (2004) Hydrology of the Danube Delta [in Russian] (Moscow).

Minakov, M.A. (2014) The Modern and Revolution in Ukraine: On the Question of the Geneology of the Euromaidan [in Ukrainian], Naukovi Zapiski 154, pp. 45-53.

Mitchell, T. (2002) Rule of Experts: Egypt, Techno-Politics, Modernity, (Berkeley: California University Press).

Murphy, M. (2013) Distributed Reproduction, Chemical Violence, and Latency, The Scholar and Feminist Online 11.3.

Nakazora, M. (2016) Nature-cultures in Translation: Japanese Nature Guides Encountering Canadian Landscape, Science as Culture 25(1)

Ninetto, A. (2005) 'An Island of Socialism in a Capitalist Country': Postsocialist Russian Science and the Culture of the State, Ethnos: Journal of Anthropology 70(4), pp. 443-464.

Petryna, A. (2002) Life Exposed: Biological Citizens After Chernobyl, (Princeton NJ: Princeton University Press.

Pigareva, L. (2012) The Sunset of Europe: Why the Danube is Losing Cargo, [in Russian] Tsentr Transportnykh Strategii, October 23 available at http://cfts.org.ua/articles/48626 (Last accessed September 1, 2013).

Pritchard, S. (2011) Confluence: The Nature of Technology and the Remaking of the Rhone, (Cambridge MA: Harvard University Press).

Proekgidrostroi. (2002) Rehabilitation of Lake Sasyk's Ecosystems: Technical-Economic Justification Vols. 1-4. [in Russian] (Odessa).

Richardson, T. (2015) Conflict and Conservation in Ukraine's Danube Delta: On the Limits of Liberalism in Participatory Environmental Governance, Development and Change 46(3).

Richardson, T. (2016) The Politics of Multiplication in a Failed Soviet Irrigation Project, Or, How Sasyk Has Been Kept From the Sea, Ethnos: Journal of Anthropology (81)2.

Richardson, T \& Weszkalnys, G. (2014) Resource Materialities. Anthropological Quarterly 87 (1), pp. 5-30.

Rusev, I. (1996) Lake Sasyk as a Hostage of Ecological Senselessness. [in Russian] (Kiev: Ekho Vostoka).

Schick, L. \& Winthereik, B. (2016) Making energy infrastructure re-design a public issue: tactical oscillations and cosmopolitics, Science as Culture 25(1)

Schmid, M. (2013) Towards an Environmental History of the Danube: Understanding a Great European River Through its Transformation as a Socionatural Site, c. 1500-2000. Habilitatsionschrift. Universitat Klagenfurt, Graz, Wien.

Scott, J. (1998) Seeing Like a State: How Certain Schemes to Improve the Human Condition Have Failed, (New Haven: Yale University Press).

Shtefan, N. (2003) The Danube Delta: A Chronology of the Dispute between Man and Nature. [in Russian] Sudokhodstvo (10-11), pp. 16-17.

Star, S. L. (1999) The Ethnography of Infrastructure. American Behavioral Scientist, 43(3), pp. 377-391. 
Star, S. L. \& Ruhleder, K. (1996) Steps Toward an Ecology of Infrastructure: Borderlands of Design and Access for Large Information Spaces. Information Systems Research, 7(1), pp. 111-134.

Stengers, I. (2010) Including Nonhumans in Political Theory: Opening Pandora's Box? Political Matter: Technoscience, Democracy and Public Life, pp.3-34 (Minneapolis: University Of Minnesota Press)

Udovichenko, Ye. (2004) Danube-Black Sea Canal. Public Hearing'[in Russian], Moriak 10(326), 17 March.

Vlasenko, I. and V. Polishchuk. (2008 [1989]) The Bitter Lessons of Sasyk.[in Ukrainian] (Artsiz: Petrov Printing House).

Vasenko, O. G. et al. (2004) Social-Economic and Ecological Justification for Renewing the Hyrdological Regime of Lake Sasyk.[in Russian] (Kharkiv: Ukrainian Scientific-Research Institute of Ecological Problems. Ministry of Environmental Protection of Ukraine).

Vykhrystiuk, I. (2010) Ne mala baba klopotu Oikumen, 24, pp. 2-3.

Way, L. (2005) Kuchma’s Failed Authoritarianism. Journal of Democracy. 16(2), pp. 131-145.

Whatmore, S. (2013) Earthly Powers and Affective Environments: An Ontological Politics of Flood Risk. Theory, Culture \& Society, 30(7-8), pp. 33-50.

White, R. (1995) The Organic Machine: The Remaking of the Columbia River, (Hill and Wang).

Winthereik, B. R. and H. Verran. (2012) Ethnographic Stories as Generalizations that Intervene. Science Studies, 25(1), pp. 37-51.

Zizak, V. 2003. Hydrological Aspects of Securing Maritime Shipping in the Danube Delta, [in Russian] Delta $i$ chelovek, November 3. available at http://dbr.org.ua. 